\title{
Pengembangan getuk kacang tolo sebagai makanan selingan alternatif kaya serat
}

\author{
Product development of getuk kacang tolo as alternative high fiber snack food
}

\author{
Fenthy Marlina Safitri', Dwi Ratna Ningsih², Elza Ismail ${ }^{3}$, Waluyo ${ }^{3}$
}

\begin{abstract}
Background: Getuk is traditional food that is familiar in all age group. However, information about nutrient content and bioactive substance of getuk are not widely available. Cowpea contains phytic acid, protein and high of calcium gives many beneficial for our body. Phytic acid may decrease cholesterol level in serum and blood glucose level because its role as dietary fiber. Protein and calcium are macro nutrient which have important roles to build our body.

Objectives: This research aimed to know the differences in qualitative and quantitative sensory characteristic, phytic acid, protein, and calcium levels of getuk kacang tolo with variations of cowpea.

Methods: This study was quasi experimental research with simple random design using 4 treatments, 2 replicates, and 2 experiment units. Getuk were made from cassava and substituted with cowpea with different concentration, e.g. $0 \%$ as control, $25 \%, 50 \%$ and $75 \%$. Sensory characteristics were assessed qualitatively by description and quantitatively by using 25 panelists. Quantitative sensory data were analyzed using statistical tests of Kruskal Wallis continued with Mann-Whitney analysis if there were a difference result. Phytic acid, protein, and calcium levels were analyzed using statistical test Anova continued with Tukey test if there were a difference result.

Results: Substitution of cowpea made getuk became darker, the texture became less chewiness, whereas aroma and flavor still the same with the control. Panelist preferred color, texture, aroma, and flavor of getuk with concentration of cowpea substitution 50\%, 75\%, 25\%, and 50\%, respectively. Phytic acid levels in $100 \mathrm{~g}$ material with the substitution of cowpea $0 \%, 25 \%, 50 \%$ and $75 \%$ were $12.5 \mathrm{mg} ; 42.8 \mathrm{mg} ; 57.9 \mathrm{mg}$; $69.2 \mathrm{mg}$ respectively. Protein level on $0 \%, 25 \%, 50 \%$ and $75 \%$ were $1.16 \mathrm{~g} ; 2.96 \mathrm{~g} ; 4.56 \mathrm{~g} ; 6.13 \mathrm{~g}$ also calcium level on 0\%, 25\%, 50\% and 75\% were $237.2 \mathrm{mg} ; 388.1 \mathrm{mg} ; 596.27 \mathrm{mg} ; 736.57 \mathrm{mg}$.

Conclusions: Different variations of cowpea substitution in producing getuk kacang tolo had the impact on sensory characteristics, phytic acid, calcium, and protein levels.
\end{abstract}

KEYWORDS: cowpea, getuk, sensory characteristic, phytic acid, calcium, protein

\begin{abstract}
ABSTRAK
Latar belakang: Getuk merupakan makanan tradisional yang familiar di semua golongan usia, namun kandungan zat gizi dan zat bioaktif pada getuk belum tersedia. Kacang tolo mengandung asam fitat, protein dan kalsium yang bermanfaat bagi tubuh. Asam fitat dapat menurunkan kadar kolesterol dan mengurangi kadar glukosa darah karena termasuk ke dalam serat pangan. Protein dan kalsium memiliki peran penting dalam tubuh yang merupakan zat gizi makro yang bermanfaat untuk membangun tubuh.

Tujuan: Mengetahui perbedaan sifat sensoris kualitatif dan kuantitatif, kadar asam fitat, protein dan kalsium pada getuk kacang tolo dengan variasi pencampuran kacang tolo.

Metode: Jenis penelitian ini adalah eksperimen semu dengan rancangan acak sederhana (RAS) menggunakan 4 perlakuan, 2 kali ulangan, dan 2 unit percobaan. Sampel penelitian adalah getuk kacang tolo dengan pencampuran kacang tolo $0 \%$ sebagai kontrol, 25\%, 50\% dan 75\%. Sifat sensoris dianalisis secara kualitatif melalui deskripsi dan kuantitatif menggunakan 25 panelis. Analisis data sifat sensoris
\end{abstract}

\footnotetext{
1 Jurusan Gizi Poltekkes Yogyakarta, Jl. Tatabumi No.3 Banyuraden, Gamping, Sleman, Yogyakarta 55293, e-mail: ms.fenthy@yahoo.com,

2 Puskesmas Turi Sleman, Jalan Pakem-Turi, Randusongo, Donokerto, Turi, Sleman, DIY

${ }^{3}$ Poltekkes Kemenkes Yogyakarta, Jl. Tatabumi No.3 Banyuraden, Gamping, Sleman, Yogyakarta 55293
} 
menggunakan uji statistik Kruskal Wallis dilanjutkan Mann-Whitney jika ada perbedaan. Kadar asam fitat, protein dan kalsium dianalisis dengan Anova dilanjutkan uji Tukey jika ada perbedaan.

Hasil: Pencampuran kacang tolo pada getuk kacang tolo menghasilkan warna semakin kecokelatan, tekstur semakin tidak kenyal, aroma dan rasa sama dengan kontrol. Warna getuk kacang tolo dengan pencampuran kacang tolo 50\%, tekstur getuk dengan pencampuran kacang tolo $75 \%$, aroma getuk dengan pencampuran kacang tolo 25\%, dan rasa dengan pencampuran kacang tolo 50\% dinilai paling disukai panelis. Kadar asam fitat dalam $100 \mathrm{~g}$ getuk dengan pencampuran kacang tolo 0\%, 25\%, 50\% dan $75 \%$ berturut-turut adalah 12,5 mg; 42,8 mg; 57,9 mg; 69,2 mg. Kadar protein 0\%, 25\%, 50\% and 75\% sebanyak 1,16 g; 2,96 g; 4,56 g; 6,13 g dan kadar kalsium 237,2 mg; 388,1 mg; 596,27 mg; 736,57 mg berturut-turut.

Kesimpulan: Variasi pencampuran kacang tolo pada pembuatan getuk kacang tolo berpengaruh terhadap sifat fisik, organoleptik, dan kadar asam fitat.

KATA KUNCI: kacang tolo, getuk, sifat sensoris, kadar asam fitat, protein, kalsium

\section{PENDAHULUAN}

Pola konsumsi pangan selama ini hanya didominasi oleh beberapa bahan pangan tertentu saja, antara lain: kedelai, kacang hijau, dan kacang tanah pada tahun 2011 yang jumlahnya hanya mencapai $0,3 \mathrm{gram} / \mathrm{kapita/hari} \mathrm{(1).} \mathrm{Tingkat}$ konsumsi pangan sumber protein pada tahun 2011 sebesar 95,9 gram/kapita/hari dan didominasi dari kelompok pangan hewani, masih kurang dibandingkan standar konsumsi ideal sebesar 150 gram/kapita/hari (1). Sementara konsumsi kalsium pada kelompok remaja putri masih kurang dari AKG yaitu sebesar 51,7-55,9\% dari kebutuhan (2). Hal ini mencerminkan bahwa tingkat konsumsi masyarakat belum mencapai keberagaman. Hasil pertanian dari kacang tolo di Indonesia sebesar 1,5-2,0 ton/ha (3). Melihat ketersediaannya yang cukup melimpah, kacang tolo memiliki potensi untuk dikembangkan karena sejauh ini hanya dimanfaatkan sebagai sayuran yaitu campuran gudeg dan lodeh, makanan tradisional yaitu sebagai campuran lepet ketan.

Kacang tolo memiliki kandungan zat gizi di antaranya 22,4 gram protein, 1,9 gram lemak, dan karbohidrat sebanyak 56,6 gram (4). Kacang tolo juga mengandung komponen bioaktif yang juga bermanfaat untuk tubuh yaitu asam fitat sebanyak 2,68 gram dalam 100 gram bahan (5). Menurut Kumar (6), asam fitat dapat menurunkan kadar kolesterol selain juga dapat mengurangi kadar glukosa darah. Di samping itu, kacang tunggak memiliki kandungan kalsium yang cukup tinggi yaitu sebesar $481 \mathrm{mg}$ per 100 gram bahan (4).
Penelitian sebelumnya berjudul pengaruh perlakuan pendahuluan dan konsentrasi tepung kacang tunggak (Cowpea sp.) terhadap sifat fisik dan tingkat kesukaan oyek (7). Berdasarkan penelitian tersebut, pembuatan oyek dengan tambahan tepung kacang tunggak menghasilkan oyek berprotein tinggi. Oyek dengan penambahan tepung kacang tunggak berpengaruh terhadap tekstur dan warna produk. Perbedaan penelitian ini terdapat pada produk yang dihasilkan, tujuan, metode penelitian. Persamaan penelitian ini terdapat pada bahan dasar pembuatan produk yaitu kacang tolo/ kacang tunggak.

Getuk singkong dengan bahan dasar berupa singkong dicampurkan dengan kacang tolo yang mengandung asam fitat sebagai zat bioaktif yang bermanfaat bagi tubuh. Salah satu bentuk inovasi makanan tradisional baru yaitu getuk kacang tolo. Berdasarkan uraian di atas, untuk mengetahui kadar asam fitat, kadar protein, dan kalsium dalam getuk kacang tolo serta daya terima dari inovasi makanan tradisional ini, maka diperlukan penelitian terhadap getuk kacang tolo berdasarkan sifat fisik, organoleptik, kadar asam fitat, protein, dan kalsium. Tujuan dari penelitian ini adalah untuk mengetahui perbedaan variasi pencampuran kacang tolo pada getuk kacang tolo ditinjau dari sifat fisik, organoleptik dan kadar asam fitat, protein dan kalsium.

\section{BAHAN DAN METODE}

Penelitian ini merupakan penelitian eksperimental semu dengan menggunakan 
rancangan acak sederhana (RAS) yaitu dengan 4 macam perlakuan (k), 2 unit penelitian dengan 2 kali pengulangan sehingga terdapat 16 unit percobaan. Perlakuan variasi campuran singkong dan kacang tolo adalah 100\%:0\% (kontrol), 75\%:25\%, 50\%: 50\% dan 25\%:75\%.

Waktu penelitian dilakukan sejak bulan Oktober sampai Mei 2015. Pengujian sifat sensoris dilakukan secara kualitatif dan kuantitatif. Uji sensoris kualitatif dilakukan secara deskriptif terhadap karakteristik warna, aroma, rasa, dan tekstur. Uji sensoris kuantitatif dilakukan menggunakan uji kesukaan oleh 25 panelis agak terlatih yang dipilih dari mahasiswa semester VI Jurusan Gizi Politeknik Kesehatan Kemenkes Yogyakarta. Hasilnya kemudian dianalisis dengan statistik non-parametric menggunakan uji K-independent samples (KruskallWallis) yang dilanjutkan dengan uji Mann-Whitney. Kadar asam fitat yang diperoleh dengan uji Makower, Wheeler dan Ferrel. Uji protein dilakukan dengan metode Kjeldahl yang dapat diketahui jumlah protein kasar $(\% \mathrm{~N})$ dalam getuk. Kadar kalsium dianalisis menggunakan metode oksidimetri. Hasil ketiga analisa tersebut selanjutnya diuji statistik dengan Annova kemudian dilanjutkan dengan Tukey Test jika ditemukan perbedaan.

\section{HASIL}

\section{Deskripsi sifat sensoris getuk kacang tolo}

Sifat sensoris secara deskriptif yang dihasilkan dari keempat variasi getuk kacang tolo dengan perbandingan pencampuran kacang tolo $0 \%, 25 \%$, $50 \%$, dan $75 \%$ memiliki perbedaan terhadap warna, tekstur, aroma serta rasa (Tabel 1). Warna kacang tolo semakin gelap sejalan dengan peningkatan campuran kacang tolo pada getuk kacang tolo.

Hasil deksripsi sifat sensoris terhadap warna pada getuk kacang tolo tanpa pencampuran kacang tolo serta getuk singkong dengan pencampuran kacang tolo memiliki warna yang berbeda. Semakin meningkat level kacang tolo yang ditambahkan ke dalam getuk menyebabkan getuk semakin berwarna gelap yaitu berwarna coklat. Perbedaan warna tersebut disebabkan oleh kulit ari dari kacang tolo yang sengaja tidak dihilangkan dalam proses pembuatan getuk.

Campuran kacang tolo pada getuk memiliki pengaruh pada tekstur kekompakan getuk. Peningkatan konsentrasi kacang tolo membuat tekstur getuk semakin tidak kompak. Hal tersebut disebabkan adanya kulit ari yang masih menempel pada biji kacang tolo. Sejalan dengan peningkatan campuran kacang tolo pada getuk, aroma khas singkong semakin mengalami penurunan sehingga aroma pada variasi kacang tolo $75 \%$ yang dicampurkan ke dalam getuk kacang tolo memiliki aroma khas kacang tolo yang paling kuat diantara variasi lain yang dilakukan.

Getuk kacang tolo tanpa pencampuran kacang tolo serta perlakuan variasi pencampuran dengan kacang tolo menghasilkan rasa yang berbeda-beda. Getuk kacang tolo tanpa campuran kacang tolo merupakan kontrol dan memiliki rasa khas singkong.

\section{Uji kesukaan getuk kacang tolo}

Uji kesukaan getuk kacang tolo yang dilakukan meliputi warna, tekstur, aroma, dan rasa. Hedonic scale test digunakan untuk menilai tingkat kesukaan panelis pada sampel dengan skala penilaian antara 3 sampai dengan 8 . Hasil uji kesukaan dapat dilihat pada Tabel 2.

Hasil uji statistik menggunakan uji KruskalWallis menunjukkan bahwa terdapat perbedaan yang signifikan pada tingkat kesukaan panelis terhadap warna getuk kacang tolo dari empat variasi perlakuan. Hal ini dibuktikan hasil nilai $p$

Tabel 1. Deskripsi sifat sensoris getuk

\begin{tabular}{ccccc}
\hline \multirow{2}{*}{ Perlakuan } & Warna & Tekstur & Sifat sensoris & Rasa \\
\cline { 2 - 4 } & Putih kekuningan & Kenyal & Khas singkong & Khas singkong \\
Singkong 100\%:kacang tolo 0\% & Put & Agak khas singkong \\
Singkong 75\%:kacang tolo 25\% & Putih coklat muda & Agak kenyal & Agak khas singkong & Agak \\
Singkong 50\%:kacang tolo 50\% & Putih coklat & Agak kenyal & Agak khas kacang tolo & Agak khas kacang tolo \\
Singkong 25\%:kacang tolo 75\% & Putih coklat tua & Tidak kenyal & Khas kacang tolo & Khas kacang tolo \\
\hline
\end{tabular}


Tabel 2. Hasil uji kesukaan getuk kacang tolo

\begin{tabular}{ccccc}
\hline \multirow{2}{*}{ Perlakuan } & \multicolumn{4}{c}{ Mean Rank } \\
\cline { 2 - 5 } & Warna & Tekstur & Aroma & Rasa \\
\hline Singkong 100\%:kacang tolo 0\% & $47,16^{\mathrm{ab}}$ & $34,90^{\mathrm{a}}$ & $42,88^{\mathrm{a}}$ & $49,16^{\mathrm{a}}$ \\
Singkong 75\%:kacang tolo 25\% & $36,24^{\mathrm{a}}$ & $59,08^{\mathrm{b}}$ & $58,26^{\mathrm{a}}$ & $43,76^{\mathrm{a}}$ \\
Singkong 50\%:kacang tolo 50\% & $62,34^{\mathrm{b}}$ & $46,42^{\mathrm{ab}}$ & $55,34^{\mathrm{a}}$ & $55,14^{\mathrm{a}}$ \\
Singkong 25\%:kacang tolo 75\% & $56,26^{\mathrm{b}}$ & $61,60^{\mathrm{b}}$ & $45,52^{\mathrm{a}}$ & $53,94^{\mathrm{a}}$ \\
nilai p (probabilitas) & 0,003 & 0,001 & 0,098 & 0,394 \\
\hline
\end{tabular}

Keterangan :

Notasi huruf yang berbeda $(a, b)$ pada kolom yang sama menyatakan ada perbedaan yang signifikan pada uji Mann-Whitney

(probabilitas) $<0,05$ yaitu 0,003. Berdasarkan Tabel 2 hasil mean rank warna getuk kacang tolo yang paling tinggi adalah pencampuran $50 \%$ kacang tolo yaitu 62,34 . Semakin tinggi hasil mean rank, maka warna getuk kacang tolo semakin disukai. Dengan demikian warna getuk kacang tolo yang paling disukai adalah pencampuran kacang tolo sebanyak $50 \%$.

Variasi pembuatan getuk kacang tolo memiliki perbedaan terhadap kenampakan tekstur. Hasil uji statistik menggunakan uji Kruskal-Wallis menunjukkan bahwa ada perbedaan yang signifikan pada tingkat kesukaan panelis terhadap keempat variasi campuran getuk. Hal ini dibuktikan hasil nilai $p$ (probabilitas) $<0,05$ yaitu 0,035 . Hasil mean rank tekstur getuk kacang tolo yang paling tinggi adalah pencampuran $75 \%$ yaitu 61,60 .

Berdasarkan Tabel 2 hasil mean rank aroma getuk kacang tolo yang paling tinggi adalah pencampuran $25 \%$ yaitu 58,26 . Hal tersebut disebabkan aroma langu pada getuk tidak begitu kuat dan hampir sama dengan kontrol dibandingkan variasi pencampuran kacang tolo $50 \%$ dan $75 \%$ yang aroma langunya dirasakan panelis begitu kuat. Hal ini menyebabkan aroma yang paling disukai adalah variasi getuk dengan pencampuran kacang tolo sebanyak $25 \%$.

Keempat variasi pencampuran kacang tolo $0 \%$, $25 \%, 50 \%$, dan $75 \%$ memiliki hasil yang berbedabeda, tetapi perbedaan tersebut tidak menunjukkan perbedaan yang nyata berdasarkan hasil uji statistik. Hal ini dibuktikan hasil uji organoleptik menggunakan uji Kruskal-Wallis menunjukkan bahwa tidak terdapat perbedaan yang signifikan pada tingkat kesukaan panelis terhadap tekstur getuk kacang tolo dengan nilai p (probabilitas) $>0,05$ yaitu 0,394 . Berdasarkan Tabel 2 hasil mean rank tekstur getuk kacang tolo yang paling tinggi adalah pencampuran kacang tolo sebanyak $50 \%$ yaitu 55,14 . Dengan demikian rasa yang paling disukai adalah pencampuran kacang tolo sebanyak $50 \%$.

\section{Kadar asam fitat getuk kacang tolo}

Uji asam fitat pada getuk kacang tolo dengan variasi pencampuran kacang tolo dilakukan dengan dua kali ulangan dan dua kali unit percobaan pada setiap perlakuannya. Pengujian ini dilakukan dengan tujuan untuk mengetahui kadar asam fitat pada getuk kacang tolo. Analisis kadar asam fitat dilakukan dengan menggunakan metode Makower, Wheeler, dan Ferrel. Kadar asam fitat pada empat sampel getuk kacang tolo dapat dilihat pada Tabel 3.

Tabel 3. Kadar asam fitat pada getuk kacang tolo

\begin{tabular}{cc}
\hline Perlakuan & $\begin{array}{c}\text { Kadar asam fitat } \\
\text { (mg dalam 100 g bahan) }\end{array}$ \\
\cline { 2 - 2 } & Rata-rata \\
\hline Singkong 100\%:kacang tolo 0\% & $12,5^{\mathrm{a}}$ \\
Singkong 75\%:kacang tolo 25\% & $42,8^{\mathrm{b}}$ \\
Singkong 50\%:kacang tolo 50\% & $57,9^{\mathrm{c}}$ \\
Singkong 25\%:kacang tolo 75\% & $69,2^{\mathrm{d}}$ \\
nilai p (probabilitas) & 0,002 \\
\hline
\end{tabular}

Keterangan :

Notasi huruf yang berbeda $(a, b, c, d)$ pada kolom yang sama menyatakan ada perbedaan yang signifikan pada uji One Way Anova

Berdasarkan hasil analisis kadar asam fitat pada getuk kacang tolo dengan variasi pencampuran kacang tolo $0 \%, 25 \%, 50 \%$, dan $75 \%$ diketahui bahwa kadar asam fitat paling tinggi terdapat pada getuk kacang tolo dengan variasi pencampuran kacang tolo 
$75 \%$. Semakin tinggi persentase tambahan kacang tolo, kadar asam fitat akan semakin bertambah. Berdasarkan uji One Way Anova dapat disimpulkan bahwa ada perbedaan kadar asam fitat pada getuk kacang tolo antarsampel.

\section{Kadar protein getuk kacang tolo}

Uji protein pada variasi pencampuran kacang tolo getuk kacang tolo dilakukan dengan dua kali ulangan dengan dua kali unit percobaan pada empat perlakuan yaitu variasi pencampuran kacang tolo $0 \%, 25 \%, 50 \%$, dan $75 \%$. Hasil yang diperoleh kemudian diuji dengan menggunakan uji statistik yaitu dengan uji One Way Anova untuk mengetahui perbedaannya dan dilanjutkan dengan uji Tukey apabila terdapat perbedaan. Kadar protein pada empat sampel getuk kacang tolo dapat dilihat pada Tabel 4.

Tabel 4. Kadar protein getuk kacang tolo

\begin{tabular}{lc}
\hline Perlakuan & Kadar protein (\%) \\
\cline { 2 - 2 } & Rata-rata \\
\hline Singkong 100\%:kacang tolo 0\% & $1,16^{\mathrm{a}}$ \\
Singkong 75\%:kacang tolo 25\% & $2,96^{\mathrm{b}}$ \\
Singkong 50\%:kacang tolo 50\% & $4,56^{\mathrm{c}}$ \\
Singkong 25\%:kacang tolo 75\% & $6,13^{\mathrm{d}}$ \\
nilai p (probabilitas) & 0,000 \\
\hline
\end{tabular}

\section{Keterangan :}

Notasi huruf yang berbeda $(a, b, c, d)$ pada kolom menyatakan ada perbedaan yang signifikan pada uji One Way Anova

Berdasarkan hasil analisis kadar protein pada getuk kacang tolo dengan variasi pencampuran kacang tolo $0 \%, 25 \%, 50 \%$, dan $75 \%$ diketahui bahwa kadar protein paling tinggi terdapat pada getuk kacang tolo dengan variasi pencampuran kacang tolo sebesar $75 \%$, sedangkan kandungan protein paling rendah terdapat pada getuk singkong tanpa pencampuran kacang tolo. Semakin tinggi persentase campuran kacang tolo, maka kadar protein akan semakin bertambah.

Berdasarkan hasil uji menggunakan One Way Anova dengan $\mathrm{p}<0,05$ yang menunjukkan bahwa ada perbedaan bermakna kadar protein dari keempat variasi pencampuran, dibuktikan dengan $p<0,05$ yaitu 0,000 yang kemudian dilanjutkan dengan uji Tukey. Ada perbedaan kadar protein pada getuk kacang tolo antarsampel.

\section{Kadar kalsium getuk kacang tolo}

Uji kalsium pada getuk singkong dengan campuran kacang tolo dilakukan dengan dua kali ulangan dan dua kali unit percobaan pada setiap perlakuannya. Pengujian ini dilakukan dengan tujuan untuk mengetahui kadar kalsium pada getuk ini. Analisis kadar kalsium dilakukan dengan metode oksidimetri (Tabel 5).

Tabel 5. Kadar kalsium getuk kacang tolo

\begin{tabular}{lc}
\hline Perlakuan & $\begin{array}{c}\text { Kadar kalsium } \\
\text { (mg/100 g) }\end{array}$ \\
\cline { 2 - 2 } & Rata-rata \\
\hline Singkong 100\%:kacang tolo 0\% & $237,2^{\mathrm{a}}$ \\
Singkong 75\%:kacang tolo 25\% & $388,1^{\mathrm{b}}$ \\
Singkong 50\%:kacang tolo 50\% & $596,27^{\mathrm{c}}$ \\
Singkong 25\%:kacang tolo 75\% & $736,57^{\mathrm{d}}$ \\
nilai p (probabilitas) & 0,000 \\
\hline
\end{tabular}

Keterangan :

Notasi huruf yang berbeda $(a, b, c, d)$ pada kolom menyatakan ada perbedaan yang signifikan pada uji One Way Anova

Berdasarkan hasil analisis kadar kalsium pada getuk kacang tolo dengan variasi pencampuran kacang tolo $0 \%, 25 \%, 50 \%$, dan $75 \%$ diketahui bahwa kadar kalsium paling tinggi terdapat pada getuk kacang tolo dengan variasi pencampuran kacang sebesar $75 \%$. Semakin tinggi persentase campuran kacang tolo maka kadar kalsium akan semakin bertambah.

Berdasarkan hasil uji menggunakan One Way Anova dengan $p<0,05$, menunjukkan bahwa ada perbedaan bermakna kadar kalsium dari keempat variasi pencampuran, dibuktikan dengan signifikan $p<0,05$ yaitu 0,000 . Hal ini dapat disimpulkan bahwa ada perbedaan terhadap kadar kalsium pada getuk kacang tolo antarsampel.

\section{BAHASAN}

\section{Uji fisik dan organoleptik getuk kacang tolo}

Berdasarkan Tabel 2, warna putih kekuningan hanya dimiliki oleh kontrol, warna putih kecoklatan pada getuk dengan substitusi kacang tolo $25 \%$, 
warna putih coklat untuk substitusi 50\% kacang tolo, dan substitusi $75 \%$ kacang tolo memiliki warna putih coklat tua. Warna kecoklatan pada getuk dengan campuran kacang tolo disebabkan oleh pigmen yang secara alami terdapat pada kacang tolo. Kacang tolo mengandung pigmen antosianin yang berwarna gelap merah kecoklatan (8). Antosianin adalah suatu kelas dari senyawa flavonoid yang secara luas terbagi dalam polifenol tumbuhan (6). Pigmen inilah yang memberikan warna pada getuk dengan campuran kacang tolo. Sejalan dengan peningkatan konsentrasi kacang tolo yang dicampurkan pada getuk kacang tolo menghasilkan getuk yang semakin coklat.

Hal yang sama juga ditemui pada penelitian dengan pencampuran kacang tolo yang ditambahkan dalam produk lain. Pemberian campuran tepung kacang tolo pada produk oyek menghasilkan perbedaan warna. Penambahan tepung kacang tolo yang semakin banyak memberikan warna yang semakin gelap pada produk oyek yang dihasilkan (7). Penelitian yang serupa juga ditemukan bahwa peningkatan jumlah kacang tolo yang ditambahkan pada nugget membuat produk semakin berwarna merah gelap (9).

Perbedaan warna tersebut disebabkan oleh kulit ari dari kacang tolo yang sengaja tidak dihilangkan dalam proses pembuatan getuk. Hal tersebut disebabkan untuk memberikan inovasi warna terhadap getuk yang selama ini identik dikenal berwarna putih kekuningan khas singkong.

Pada uji sifat fisik tekstur dilakukan menggunakan indra peraba dengan cara menekan getuk dengan tangan untuk mengetahui tingkat kekenyalannya. Campuran kacang tolo pada getuk memiliki pengaruh pada tekstur kekompakan getuk kacang tolo yang berbeda. Peningkatan konsentrasi kacang tolo membuat tekstur getuk semakin tidak kompak. Hal tersebut disebabkan adanya kulit ari yang masih menempel pada biji kacang tolo. Berdasarkan penelitian yang dilakukan oleh Ratnaningsih (10), pencampuran kacang tolo yang dilakukan pada pembuatan tempe menghasilkan tekstur tempe yang tidak kompak sejalan dengan peningkatan konsentrasi kacang tolo yang diberikan.

Kadar air dari bahan dasar yang digunakan dalam pembuatan getuk juga memiliki pengaruh terhadap perbedaan tekstur dari keempat variasi yang dilakukan. Menurut Litbang, Deptan RI (1), kadar air pada kacang tolo sekitar $10 \%$, sedangkan pada singkong kadar airnya mencapai $30 \%$. Sejalan dengan peningkatan konsentrasi kacang tolo yang dicampurkan pada getuk membuat tekstur dari getuk semakin tidak kompak disebabkan oleh kadar airnya yang rendah.

Langu pada kacang kacangan ini disebabkan adanya enzim lipoksidase yang terdapat pada biji kacang (11). Hal ini terjadi karena enzim lipoksidase menguraikan atau menghidrolisis lemak pada kacang tolo menjadi senyawasenyawa penyebab bau langu yang tergolong pada kelompok heksanal dan heksanol. Hal ini terjadi karena enzim lipoksidase menguraikan atau menghidrolisis lemak pada kacang tolo menjadi senyawa-senyawa penyebab bau langu yang tergolong pada kelompok heksanal dan heksanol. Senyawa-senyawa tersebut dalam konsentrasi rendah sudah dapat menyebabkan bau langu (12). Kandungan lemak pada kacang tolo lebih tinggi dibandingkan dengan singkong yaitu 1,9 gram dan 0,3 gram, sehingga aroma atau bau langu lebih kuat pada getuk yang diberi campuran kacang tolo. Semakin banyaksubstitusi kacang tolo yang diberikan, semakin kuat aroma kacang khas langu yang dihasilkan.

Getuk dengan substitusi kacang tolo sebesar $25 \%$ memiliki rasa agak khas singkong, sedangkan pada substitusi kacang tolo $50 \%$ memiliki rasa agak khas kacang tolo. Substitusi kacang tolo sebesar $75 \%$ menghasilkan getuk yang memiliki rasa sangat khas kacang tolo yaitu langu atau "off-flavor". Dengan demikian peningkatan konsentrasi kacang tolo pada getuk akan membuat peningkatan rasa khas kacang tolo pada getuk.

Rasa off-flavor adalah rasa pahit dan rasa kapur yang disebabkan adanya senyawa-senyawa glikosida dalam kacang tolo. Rasa pahit disebabkan oleh glikosida jenis sapogenol. Senyawa glikosida lain yang menyebabkan off-flavor adalah isoflavon dan gugus aglikonnya. Glikosida tersebut menyebabkan timbulnya rasa kapur pada kacang (13).

Sejalan dengan peningkatan konsentrasi pencampuran kacang tolo dalam getuk singkong 
akan meningkatkan kadar asam fitat dalam getuk. Substitusi kacang tolo sebanyak $75 \%$ merupakan variasi yang paling banyak mengandung asam fitat. Kandungan asam fitat juga ditemukan pada kontrol sebesar 12,5 gram/100 gram getuk, sehingga dapat diketahui di dalam getuk singkong pun mengandung asam fitat. Menurut referensi yang diperoleh, umbiumbian tidak mengandung asam fitat sehingga perlu ada tinjauan ulang serta penelitian lebih lanjut mengenai keberadaan asam fitat pada kontrol dan faktor penyebabnya.

Proses pengolahan pada kacang tolo ternyata memiliki dampak penurunan terhadap kadar asam fitat pada kacang tolo. Berdasarkan hasil penelitian Almasyhuri (5) tahun 1990, kandungan asam fitat pada kacang tolo diketahui 2,68 gram setelah mengalami pengolahan menjadi produk getuk penurunan kadar asam fitat cukup banyak.

Proses pengolahan getuk diawali dengan perendaman kacang tolo mentah yang dilakukan selama 4 jam. Menurut Suhardi dalam Pangastuti (14) selama perendaman terjadi difusi yang menyebabkan kadar asam fitat pada kacang tolo menurun. Selain itu juga disebabkan terlarutnya asam fitat pada air rendaman.

Pada tahap perendaman terjadi perubahan secara fisik pada kacang tolo. Perubahan tersebut yaitu biji kacang tolo menjadi lebih lunak dan lebih besar karena banyak menyerap air. Hal ini akan mengurangi kesulitan pada tahap pengolahan selanjutnya. Asam fitat bersifat sangat larut dalam air serta banyak terkandung dalam kulit kacangkacangan. Proses pengukusan mengakibatkan terjadinya absorbsi air dalam bentuk uap panas, sehingga terjadi hidrasi air, namunair tidak mudah mengalami difusi ke dalam kacang tolo. Hal ini yang menyebabkan penurunan kadar asam fitat pada proses pengukusan tidak begitu besar apabila dibandingkan dengan proses pengolahan dengan panas lainnya (15).

\section{Kadar asam fitat getuk kacang tolo}

Asam fitat tersedia dalam bahan pangan tentunya tidak dalam bentuk tunggal yang berdiri sendiri. Zat anti gizi ini tersedia dalam bahan pangan bersama dengan serat, mineral, dan komponen fitokimia lainnya yang secara alami ada pada tanaman. Sangat sulit untuk mengevaluasi penyerapan mineral dan bioavailibitas makanan yang juga mengandung tinggi asam fitat hanya dengan melihat kandungan fitatnya (16). Di sisi lain, asam fitat memiliki banyak manfaat bagi kesehatan manusia, diantaranya untuk menjaga kesehatan gigi dan mulut, mencegah resorpsi tulang, menurunkan kadar kolesterol, penawar keracunan timah hitam (17). Menurut Kumar (6), asam fitat dapat menurunkan kadar kolesterol selain itu juga dapat mengurangi kadar glukosa darah karena asam fitat dapat mengubah karbohidrat menjadi serat pangan. Penggunaan asam fitat dengan kadar yang wajar di dalam makanan dinilai cukup aman dan tidak mengganggu proses penyerapan mineral dan protein dari bahan makanan. Karena alasan manfaat dan nilai kesehatan ataupun sifatnya sebagai antioksidan alami, maka di beberapa negara asam fitat telah diizinkan untuk digunakan sebagai bahan tambahan pada makanan (3).

Asupan fitat pada vegetarian rata-rata adalah 2.000-2.600 mg. Sementara konsumsi harian pada penduduk biasa berkisar 150-144 mg (6). Kandungan asam fitat pada getuk paling banyak terdapat pada substitusi kacang tolo $75 \%$ dengan kandungan asam fitat sebanyak 69,2 mg. Dengan membandingkan rata-rata konsumsi harian asam fitat, getuk substitusi kacang tolo $75 \%$ yang dikonsumsi dua kali dalam sehari (makanan selingan pagi dan sore) dengan porsi 100 gram setiap makan, jumlah asupan fitat masih di bawah asupan rata-rata harian yaitu $138,4 \mathrm{mg}$. Dengan demikian inovasi makanan tradisional yang mengandung asam fitat ini aman untuk dikonsumsi karena masih dalam batas wajar.

\section{Kadar protein getuk kacang tolo}

Berdasarkan studi literatur kandungan protein pada getuk singkong sangat rendah yaitu 0,5 gram/100 gram bahan, sedangkan kandungan protein pada kacang tolo sebesar 22,4 gram/100 gram. Penambahan kacang tolo pada getuk singkong dapat meningkatkan kandungan protein pada getuk. Berdasarkan hasil analisis kadar protein pada empat variasi pencampuran kacang tolo 
menunjukkan bahwa semakin banyak kacang tolo yang dicampurkan, maka kandungan protein pada getuk semakin meningkat.

Berdasarkan penelitian yang dilakukan oleh Dewanti (18), peningkatan proporsi kacang tunggak menyebabkan peningkatan kadar protein pada tepung bubur sereal instan. Hal ini sejalan dengan peningkatan variasi pencampuran kacang tolo pada getuk singkong semakin meningkatkan kandungan protein.

Hasil uji organoleptik dari aroma serta rasa yang dilakukan menunjukkan bahwa hasil yang paling banyak disukai yaitu getuk dengan substitusi kacang $75 \%$. Hal ini menunjukkan bahwa semakin banyak kandungan protein akan mempengaruhi rasa serta aroma makanan. Proses pemanasan menyebabkan protein dalam bahan pangan mengalami perubahan dan membentuk persenyawaan dengan bahan lain yang membentuk rasa dan aroma makanan. Protein makanan juga memiliki sifat fungsional dalam pembentukan dan pengikatan rasa (19).

Protein merupakan senyawa komplek yang terdiri dari asam amino. Tidak semua asam amino dapat dibentuk dalam tubuh. Asam amino esensial ini yang dapat diperoleh dari makanan sehari-hari. Kacang-kacangan serta hasil olahannya salah satu sumber asam amino (11). Getuk dengan bahan dasar singkong dan kacang tolo mengandung tinggi protein yang memiliki peranan bagi tubuh dan merupakan inovasi makanan tradisional baru yang dapat dijadikan sumber pangan yang baik, murah, dan mudah diperoleh.

Kecukupan protein orang Indonesia dewasa sebesar $50 \mathrm{gram} /$ hari. Nilai rata-rata berdasarkan angka kecukupan gizi tahun 2013 (2), kebutuhan protein laki-laki berusia 10-18 tahun berkisar 64,6 gram/hari sedangkan laki-laki berusia 19-64 tahun kebutuhan protein rata-rata $64 \mathrm{gram} / \mathrm{hari}$. Kebutuhan rata-rata protein perempuan berusia 10-18 tahun berkisar $62,6 \mathrm{gram} /$ hari sedangkan perempuan berusia 19-64 tahun kebutuhan protein rata-rata 56,6 gram/hari. Hasil Riskesdas tahun 2007 (20) menyebutkan bahwa konsumsi rata-rata protein secara nasional sebesar $55,5 \mathrm{gram} /$ hari.

Kandungan protein pada getuk dengan susbtitusi kacang tolo $75 \%$ memiliki kandungan protein sebesar 6,13 gram/100 gram. Konsumsi getuk kacang tolo sebagai selingan untuk porsi 100 gram/hari dengan $75 \%$ campuran kacang tolo telah memenuhi asupan rata-rata protein sebesar $11,1 \%$ dari konsumsi rata-rata protein berdasarkan hasil Riskesdas tahun 2007 (20), yaitu sebesar $55,5 \mathrm{gram} / \mathrm{hari}$.

Kualitas konsumsi masyarakat pada tahun 2011 untuk konsumsi protein nabati dari kacangkacangan masih berada di bawah target pola pangan harapan (PPH). Skor PPH baru (1) mencapai 5,6, sedangkan target konsumsi nasional sebanyak 10. Konsumsi kacang-kacangan untuk memenuhi kebutuhan energi dalam sehari berdasarkan angka kecukupan energi (AKG) $2.000 \mathrm{kkal} / \mathrm{kap} /$ hari dari target 5\% AKG baru bisa dicapai 2,8\% AKG (2). Berdasarkan pola asupan tersebut, dengan mengonsumsi getuk kacang tolo sebagai makanan selingan sehari-hari dapat menjadi bahan pertimbangan dalam menanggulangi permasalahan tersebut karena mengonsumsi getuk kacang tolo sebagai makanan selingan dapat meningkatkan konsumsi kacang-kacangan. Getuk dengan substitusi kacang tolo $50 \%$ dapat menjadi inovasi getuk singkong karena lebih disukai panelis.

\section{Kadar kalsium getuk kacang tolo}

Kalsium merupakan salah satu nutrien esensial yang dibutuhkan untuk berbagai fungsi tubuh (21). Pada tubuh orang dewasa terdapat kalsium sebanyak $2 \%$ atau sekitar $1,0-1,4 \mathrm{~kg}$ berat badan (22). Sebagian besar (99\%) kalsium di dalam tubuh terdapat dalam jaringan keras seperti tulang dan gigi (23). Kalsium bermanfaat untuk membentuk serta mempertahankan tulang dan gigi yang sehat, mencegah osteoporosis, membantu proses pembekuan darah dan penyembuhan luka, mengirimkan signal ke dalam sel-sel saraf, mengatur kontraksi otot (24). Kekurangan kalsium menyebabkan nyeri pada otot tulang, osteoporosis, dan daya ingat berkurang (25).

Nilai rata-rata berdasarkan angka kecukupan gizi tahun 2013 (2), kebutuhan kalsium laki-laki maupun perempuan berusia 10-18 tahun yaitu 1.200 $\mathrm{mg} /$ hari sedangkan berusia 19-64 tahun kebutuhan protein rata-rata $1.033 \mathrm{mg} / \mathrm{hari}$. Kandungan kalsium 
pada getuk dengan substitusi kacang tolo $75 \%$ sebesar 763,57 mg/100 g. Konsumsi getuk kacang tolo sebagai selingan untuk porsi $100 \mathrm{gram} / \mathrm{hari}$ dengan $75 \%$ campuran kacang tolo telah memenuhi asupan kalsium sebesar $63 \%$ dari kebutuhan kalsium sehari untuk umur 10-18 tahun sedangkan 73,9\% untuk umur 19-64 tahun.

Getuk merupakan salah satu makanan tradisional yang berbahan dasar singkong. Kacang tolo memiliki kandungan kalsium yang jauh lebih tinggi dibandingkan dengan singkong dan merupakan sumber kalsium yang baik. Akan tetapi, dalam kacang tolo juga mengandung zat anti gizi salah satunya adalah asam fitat.

Zat anti gizi ini tersedia dalam bahan pangan bersama dengan serat, mineral, dan komponen fitokimia lainnya yang secara alami ada pada tanaman. Sangat sulit untuk mengevaluasi penyerapan mineral dan bioavailibitasnya dari makanan yang juga mengandung tinggi asam fitat hanya dengan melihat kandungan fitatnya (16). Penggunaan asam fitat dengan kadar yang wajar di dalam makanan dinilai cukup aman dan tidak mengganggu proses penyerapan mineral dan protein dari bahan makanan (3).

Pencampuran kacang tolo sebagai bahan pembuatan getuk dapat meningkatkan pemanfaatan serta variasi pengolahan dari kacang tolo yang selama ini pemanfaatannya relatif terbatas dan belum bervariasi. Getuk dengan pencampuran kacang tolo akan menjadi inovasi baru makan tradisional dan meningkatkan pemanfaatan pangan lokal.

Berdasarkan hasil uji sensoris kuantitatif getuk singkong dengan pencampuran kacang tolo hasilnya dapat diterima oleh panelis dan disukai. Dengan demikian getuk yang dicampurkan kacang tolo dapat dijadikan makanan selingan yang bisa mencukupi kebutuhan kalsium harian.

\section{KESIMPULAN DAN SARAN}

Berdasarkan penelitian variasi pencampuran kacang tolo pada getuk kacang tolo dapat disimpulkan bahwa semakin tinggi persentase pencampuran kacang tolo pada getuk menghasilkan sifat sensoris kualitatif warna yang semakin kecokelatan, aroma dan rasa semakin khas kacang tolo, sedangkan tekstur semakin tidak kenyal.

Hasil uji kesukaan membuktikan bahwa panelis menyukai warna getuk dengan substitusi kacang tolo sebanyak $50 \%$, tekstur pada substitusi kacang tolo $75 \%$, aroma pada substitusi kacang tolo $25 \%$, dan rasa pada substitusi kacang tolo $50 \%$. Kadar asam fitat, protein, dan kalsium makin meningkat dengan semakin banyak kacang tolo yang ditambahkan.

Pada penelitian ini, terdapat kandungan asam fitat dalam getuk tanpa substitusi kacang tolo (getuk kontrol). Pada penelitian selanjutnya diharapkan dapat ditinjau penyebab kandungan asam fitat di dalam getuk. Berdasarkan hasil uji sensoris secara kualitatif dan kuantitatif, serta kadar asam fitat pada variasi pencampuran getuk kacang tolo pencampuran $50 \%$ dapat dikembangkan lebih lanjut. Asam fitat dalam kacang tolo memilki peranan terhadap kestabilan gula darah. Diharapkan penelitian lebih lanjut dapat meninjau nilai gizi selain protein dan kalsium yang terkandung serta pengaruh indeks glikemik getuk kacang tolo, sehingga makanan tradisional ini dapat dikembangkan sebagai produk pangan fungsional berbasis bahan pangan lokal yang murah dan mudah diperoleh serta memiliki nilai gizi yang tinggi.

\section{RUJUKAN}

1. Badan Ketahanan Pangan Kementerian Pertanian RI Tahun 2012. Roadmap diversifikasi pangan tahun 2011-2015. Jakarta: Kementerian Pertanian Republik Indonesia; 2012.

2. Widyakarya Nasional Pangan dan Gizi (WNPG) $X$. Angka kecukupan gizi. Jakarta: WNPG X; 2012.

3. Sarjono P, Nies S, Agustina L, Aminin, Mulyani, Wuryanti. Profil kandungan protein dan tekstur tahu akibat penambahan fitat pada proses pembuatan tahu. Jur Kim Univ Diponegoro. 2006;9(1).

4. Persatuan Ahli Gizi Indonesia. Tabel komposisi pangan Indonesia. Jakarta: PT Elex Media Komputindo; 2010.

5. Almasyhuri, Yuniati $H$, Sabita Slamet. Kandungan asam fitat dan tanin dalam kacang-kacangan yang dibuat tempe. PGM. 1990;13:65-72. 
6. Kumar V, Sinha AK, Makkar HPS, Becker K. Dietary roles of phytate and phytase in human nutrition: a review. Food Chem [Internet]. Elsevier Ltd; 2010;120(4):945-59. Available from: http:// dx.doi.org/10.1016/j.foodchem.2009.11.052

7. Sutanti A, Sri Luwihana D, Kanetro B. Pengaruh perlakuan pendahuluan dan konsentrasi tepung kacang tunggak (cowpea) terhadap sifat fisik dan tingkat kesukaan oyek. AgriSains. 2013;4(7):11-22.

8. Ha TJ, Lee. M-H, Jeong. YN, Lee JH, Han S-I, Park $\mathrm{C}-\mathrm{H}$, et al. Anthocyanins in Cowpea (Vigna unguiculata (L.)Walp.ssp. unguiculata). Food Sci Biotechnol Kosfost. 2010;19:821-6.

9. Tiffany D. Pengaruh perlakuan awal kacang tunggak terhadap karakteristik kimia, fisik, dan organoleptik nugget kacang tunggak (Vigna unguiculata $\{\mathrm{L}\}$ Walp.). [Malang]: Universitas Negeri Malang; 2014.

10. Ratnaningsih N, Nugraheni M, Rahmawati F. Pengaruh jenis kacang tolo, proses pembuatan dan jenis inokulum terhadap perubahan zat-zat gizi pada fermentasi tempe kacang tolo. Saintek. 2009;14:97-128.

11. Nasyiin M. Variasi campuran kacang merah (Phaseolus vulgaris L.) pada pembuatan tempe ditinjau dari sifat fisik, sifat organoleptik, dan kadar protein. [Yogyakarta]: Poltekkes Kemenkes Yogyakarta; 2011.

12. Muchtadi $D$. Teknik evaluasi nilai gizi protein. Bogor; 1993.

13. Tinggi S, Pertanian P, Penyuluhan J, Yogyakarta P. Jurnal ilmu-ilmu pertanian. 2011;7.

14. Pangestuti HP, Triwibowo S. Pengaruh lama perendaman, perebusan dan pengukusan terhadap kandungan asam fitat dalam tempe kedelai [Internet]. 1996 [cited 2015 Jan 1]. Available from: http://cerminduniakedokteran. com//lama-perebusan-kacang

15. Pramita DS. Pengaruh teknik pemanasan terhadap kadar asam fitat dan aktivitas antioksidan koro benguk (Mucuna pruriens), koro glinding (Phaseolus lunatus), dan koro pedang (Panavalia ensiformis). Surakarta; 2008.

16. Lopez H, Walter, Leenhardt F, Coudry C, Remesy C. Minerals and phytic acid interactions: is it a real problem for human nutrition? Int J Food Sci Technol. 2002;37:727-39.

17. Lee BJ. Antioxidant effects of carnosine and phytic acid in model beef system. J Food Sci. 1998;63(3):394-8.

18. Dewanti T, Harijono W, Nurma S. Tepung bubur sereal instan metode ekstruksi dari sorgum dan kecambah kacang tunggak (kajian proporsi bahan dan penambahan maltodekstrin). J Teknol Pertan. 2012;3(1):35-44.

19. Rosida FD, Qomariah H, Murtiningsih. Kajian dampak substitusi kacang tolo pada kualitas fisik dan sifat kimia tahu. J Teknol Pangan. 2011;5:138-48.

20. Kementerian Kesehatan RI. Riset kesehatan dasar (Riskesdas). Jakarta: Badan Penelitian dan Pengembangan Kesehatan Kementerian Kesehatan Rl; 2007.

21. Gobinathan P, Sankar B, Murali P, Panneerselvam $R$. Interactive effects of calcium chloride on salinity-induced oxidative stress in pennisetum typoidies. Bot Res Int. 2009;2(3):143-8.

22. Winarno F. Kimia pangan dan gizi. Jakarta: Gramedia Pustaka Utama; 2008.

23. Muchtadi D, Astawan M, Palupi NS. Metabolisme zat gizi sumber, fungsi, dan kebutuhan bagi manusia. Jakarta: Pustaka Sinar Harapan; 1993.

24. Tampilang E. Pengertian, macam, dan fungsi kalsium [Internet]. 2012 [cited 2014 Jan 8]. Available from: http://paramitahilala.blogspot. com

25. Sulistyawati D. Manfat kalsium bagi tubuh anda [Internet]. 2013 [cited 2014 Jan 8]. Available from: http://dinkeskebumen.wordpress.com 